\title{
Get your chemistry right with KNIME
}

\author{
Thorsten Meinl ${ }^{1 *}$, Gregory Landrum ${ }^{2}$ \\ From 8th German Conference on Chemoinformatics: 26 CIC-Workshop \\ Goslar, Germany. 11-13 November 2012
}

KNIME (Konstanz Information Miner, [1]) is a userfriendly and comprehensive open-source data integration, processing, analysis, and exploration platform. From day one, KNIME has been developed using rigorous software engineering practices and is used by professionals in both industry and academia in over 60 countries.

In the presentation we will show some of the new features in KNIME 2.6 and give an outlook to KNIME 2.7. We also present recent developments in the KNIME Community Contributions [2], where research groups can easily provide their KNIME extensions to the community. We will focus on the freely available chemistry extensions - especially RDKit [3] - and demonstrate their usage in real-world workflows.

\footnotetext{
Author details

${ }^{1}$ University of Konstanz, Box 712, D-78457 Konstanz, Germany. ${ }^{2}$ Novartis
}

Pharma AG, Postfach, CH-4002 Basel, Switzerland.

Published: 22 March 2013

\section{References \\ 1. [http://www.knime.org/]. \\ 2. [http://tech.knime.org/community]. \\ 3. [http://www.rdkit.org/].}

doi:10.1186/1758-2946-5-S1-F1

Cite this article as: Meinl and Landrum: Get your chemistry right with KNIME. Journal of Cheminformatics 2013 5(Suppl 1):F1.
* Correspondence: Thorsten.Meinl@uni-konstanz.de

${ }^{1}$ University of Konstanz, Box 712, D-78457 Konstanz, Germany

Full list of author information is available at the end of the article

\footnotetext{
Publish with ChemistryCentral and every scientist can read your work free of charge

"Open access provides opportunities to our colleagues in other parts of the globe, by allowing anyone to view the content free of charge."

W. Jeffery Hurst, The Hershey Company.

- available free of charge to the entire scientific community

- peer reviewed and published immediately upon acceptance

- cited in PubMed and archived on PubMed Central

- yours - you keep the copyright

Submit your manuscript here:

http://www.chemistrycentral.com/manuscript/

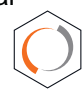

Chemistry Central
} 